\author{
Carmen García $\cdot$ Luis M. Montuenga $\cdot$ Juan F. Medina \\ Jesús Prieto
}

\title{
In situ detection of AE2 anion-exchanger mRNA in the human liver
}

Received: 18 November 1996 / Accepted: 3 July 1997

\begin{abstract}
Na}^{+}$-independent anion exchangers, a family of membrane proteins that mediate electroneutral exchanges of chloride and bicarbonate ions across the cell membrane, are considered to be involved in intracellular $\mathrm{pH}$ regulation as well as in transepithelial acid/base transport. Previous immunohistochemical data have shown that anion-exchanger-2 (AE2) protein is expressed in the liver parenchyma, localizing at both the canaliculi and the luminal surfaces of intrahepatic bile ducts, where it may have a role in the biliary secretion of bicarbonate. In the present study, we have carried out in situ hybridization experiments on biopsies of human liver using three overlapping antisense anion-exchanger- 2 riboprobes. Anion-exchanger-2 mRNA signals were localized mainly in the cytoplasm of terminal and interlobular bile-duct cells, whereas weaker signals were observed in bile-duct cells of larger intrahepatic ducts. Furthermore, some hepatocytes, mostly periportal, contained detectable anion-exchanger-2 mRNA signals in their cytoplasm. No hybridization signals were observed in controls with sense riboprobes, with omission of the antisense probe, or with treatment of the sections with RNase before hybridizations. Finally, intense anion-exchanger- 2 hybridization signals were observed in lymphomononuclear cells in sinusoids and in portal infiltrates. Immunocytochemical data from reverse-phase sections suggest that these cells cor-
\end{abstract}

The authors dedicate this article to Prof. J.J. Vázquez who died in an accident on 25 June 1995 and acknowledge his important contributions to this study prior to his death.

Supported by grants from the Spanish DGICYT (PB92-1133 and PM92-0165), the Navarra Autonomic Government, the Fundación Echébano, and the Fundación Ramón Areces.

C. García $\cdot$ L.M. Montuenga

Department of Histology and Pathology, Medical School,

University of Navarra, E-31080 Pamplona, Spain

J.F. Medina $(\square) \cdot$ J. Prieto

Department of Internal Medicine and Liver Unit,

University Clinic and Medical School, University of Navarra,

E-31080 Pamplona, Spain

Tel.: +34-48-425600, ext. 6340; Fax: +34-48-425649; E-mail: jfmedina@unav.es respond to some of the CD45R+ (UCHL1+) T lymphocytes resident in the liver.

Key words Anion exchange - Bicarbonate secretion . Bile-duct epithelial cells · Hepatocytes .

Immunohistochemistry $\cdot$ Liver lymphocytes $\cdot \mathrm{T}$ cells . Man

\section{Introduction}

$\mathrm{Na}^{+}$-independent anion exchangers (AEs) are membrane proteins that mediate electroneutral exchanges of chloride and bicarbonate ions across the cell membrane. AE proteins seem to be involved in intracellular $\mathrm{pH}$ and cell-volume regulation, as well as transepithelial acid/base transport (Kopito et al. 1989; Mason et al. 1989; Jennings 1992; Alper 1994). These proteins are encoded by a family of genes, three of which (AE1, AE2, and AE3) are well characterized (reviewed by Kopito 1990; Alper 1994). AE1 protein (also called "band 3") is the most abundant protein in the membranes of red blood cells (Fairbanks et al. 1971). Human AE1 protein has been purified and characterized (Lukakovic et al. 1981), and its cDNA has been cloned and sequenced as well (Tanner et al. 1988; Lux et al. 1989). AE2 and AE3 transcripts (and corresponding cDNAs) were identified by cross hybridization with AE1 cDNA probes (Demuth et al. 1986; Alper et al. 1988; Kopito et al. 1989; Kudrycki et al. 1990; Lindsey et al. 1990). The complete coding sequence of human kidney AE2 cDNA has also been described (Gehrig et al. 1992). Recently, the molecular cloning of the human AE2 gene has been reported (Medina et al. 1997). Expression of the AE2 gene (detected by Northern blotting, immunoblotting, or immunocytochemistry) has been reported in a variety of mammalian organs, such as choroid plexus, stomach, ileum, kidney, testis, cochlea, salivary gland, and liver (Alper et al. 1988; Kudrycki et al. 1990; Lindsey et al. 1990; Chow et al. 1992; Parkkila et al. 1993; Jons et al. 1994; Brosius et al. 1995; Negrini et al. 1995; Vázquez et al. 1995), in some of which the 
expressed protein might have a role in hydroionic fluxes into secretions. AE3 and AE3 isoforms appear to be expressed mainly in excitable tissues of the nervous system and in cardiac muscle (Kopito et al. 1989; Kudrycki et al. 1990; Linn et al. 1992, 1995; Yannoukakos et al. 1994).

According to data from Northern blot studies, AE2 mRNA expression in the liver seems to be lower than in other organs (Alper et al. 1988; Kudrycki et al. 1990). In human liver, the expression of the AE2 message has been shown by reverse transcription-polymerase chain reaction on total RNA (Prieto et al. 1993). Immunocytochemical studies on human liver, using a monoclonal antibody against a synthetic AE2 peptide, have shown that immunoreactivity is restricted to the canicular membrane of hepatocytes and to the luminal surfaces of intrahepatic bile ducts (Martínez-Ansó et al. 1994). In the present study, we use several antisense AE2 RNA probes in in situ hybridization studies to localize the expression of AE2 transcripts in liver cells.

\section{Materials and methods}

Liver specimens were obtained from patients who underwent abdominal operations because of metastases or cysts (Table 1), but had no clinical manifestations of liver dysfunction. Pieces of these livers, apparently normal in regard to function, were fixed immediately in $10 \%$ neutral formalin $(\mathrm{pH} 7.4)$ for $8-12 \mathrm{~h}$, dehydrated in ethanol of graded concentrations (70\% to absolute), and embedded in paraffin.

In situ hybridization

Sections $4 \mu \mathrm{m}$ thick were mounted on slides coated with Vectabond (SP-1800; Vector Laboratories, Burlingame, Calif., USA), dewaxed, and prepared for hybridization with RNA probes as described by Gibson and Polak (1990). Peptidase pretreatment was carried out by incubation with proteinase K (Sigma, St. Louis, Mo., USA), $20 \mu \mathrm{g} / \mathrm{ml}$ in $0.1 \mathrm{M}$ TRIS/50 mM ethylene diamine tetra-acetic acid (EDTA; pH 8) for $30 \mathrm{~min}$ at $37^{\circ} \mathrm{C}$.

AE2 riboprobes were produced from cDNAs obtained by reverse transcription-polymerase chain reaction on liver RNA. Briefly, total RNA was isolated from human livers by a modified guanidinium thiocyanate method (Chomczynski and Sacchi 1987). After reverse transcription with random hexamers (Boehringer Mannheim, Mannheim, Germany) and M-MLV reverse transcriptase (Gibco BRL, Gaithersburg, Md., USA), three overlapping cDNA fragments were produced by PCR amplification with flanking oligonucleotides ( 20-mer each). These overlapping amplicons were as follows: AE2/10 cDNA fragment (1557 bp long from nucleotides 2318 to 3874; numbering according to Medina et al. 1997); AE2/11 cDNA fragment (1471 bp long from nucleotides 888 to 2358); and AE2/ 12 cDNA fragment (1259 bp long from nucleotides 26 to 1284). cDNA fragments were cloned into pGEM-T vector (Promega, Madison, Wis., USA). Orientations within the plasmid were ascertained by sequencing on double-stranded DNA. Plasmid constructs were used to generate riboprobes after linearizing them with appropriate restriction enzymes. Labeled probes were prepared using digoxigenin-11-UTP and either T7 or SP6 RNA polymerase (Boehringer Mannheim) to synthesize sense or antisense RNA transcripts (depending on insert orientation). For each section, hybridization was performed in $15 \mu$ l hybridization buffer [ $50 \%$ formamide, $5 \times \mathrm{SSC}$, $10 \%$ dextran sulfate, $5 \times$ Denhardt's solution, $2 \%$ sodium dodecyl sulfate (SDS), $100 \mathrm{mg} / \mathrm{ml}$ herring-sperm DNA, and diethyl pyrocarbonate-treated water], supplied with $50 \mathrm{ng} / \mu \mathrm{l}$ riboprobe, for $20 \mathrm{~h}$ at $48^{\circ} \mathrm{C}$ in a moist chamber. Hybridization was followed by four washes in $2 \times \mathrm{SSC} / 0.1 \%$ SDS, 2 washes in $0.1 \times \mathrm{SSC} / 0.1 \%$ SDS at $48^{\circ} \mathrm{C}$, brief rinses in $2 \times \mathrm{SSC}$, incubation in $2 \times \mathrm{SSC}$ containing $10 \mu \mathrm{g} / \mathrm{ml}$ RNase
Table 1 Liver biopsies from five subjects with no clinical manifestation of liver dysfunction

\begin{tabular}{|c|c|c|}
\hline \multicolumn{2}{|l|}{ Patient } & \multirow[t]{2}{*}{ Pathological condition } \\
\hline $\begin{array}{l}\text { Age } \\
\text { (Years) }\end{array}$ & Sex & \\
\hline 48 & Female & Hydatidic cyst \\
\hline 28 & Male & $\begin{array}{l}\text { Hepatic donor not transplanted because of } \\
\text { areas with macroscopic alterations }\end{array}$ \\
\hline 65 & Female & $\begin{array}{l}\text { Normal liver with metastasis of colonic } \\
\text { carcinoma }\end{array}$ \\
\hline 47 & Female & $\begin{array}{l}\text { Hepatic donor not transplanted because of } \\
\text { slight cholestasis and passive hyperemia } \\
\text { (dilatation of central veins and sinusoids) }\end{array}$ \\
\hline 61 & Female & $\begin{array}{l}\text { Normal liver with metastasis of ovarian } \\
\text { carcinoma }\end{array}$ \\
\hline
\end{tabular}

(Boehringer Mannheim) at $37^{\circ} \mathrm{C}$ for $15 \mathrm{~min}$, and additional rinses in $2 \times \mathrm{SSC}$. Visualization of digoxigenin was performed by incubation with a monoclonal antibody coupled to alkaline phosphatase (anti-digoxigenin-AP Fab fragments; Boehringer Mannheim), diluted 1:500, for $2 \mathrm{~h}$ at room temperature. Nitroblue tetrazolium chloride and 5-bromo-4-chloro-3-indolyl-phosphate (Boehringer Mannheim) were used as substrates for the alkaline phosphatase. Controls included use of the sense probe, omission of the probe, and treatment of the sections with RNase before hybridization.

\section{Immunocytochemistry}

Immunostaining to determine the population of liver lymphocytes was carried out with commercial mouse monoclonal antibodies against CD antigens: anti-CD20 ( $\operatorname{IgG}_{2 \mathrm{a}}$, clone L26; Dako, Glostrup, Denmark), which is rather specific for B cells, and anti-CD45R $\left(\operatorname{IgG}_{2 \mathrm{a}}\right.$, clone UCHL1; BioGenex Laboratories, San Ramon, Calif., USA), which recognizes mature activated T cells, most thymocytes, and a subpopulation of resting T cells within the CD4 and CD8 subsets. The UCHL1 antibody also recognizes granulocytes and monocytes, but shows no reactivity with normal B cells or NK cells. Immunocytochemical staining was carried out with the avidin-biotin method (Hsu et al. 1981). Sections (4 $\mu$ m thick) of paraffin-embedded liver were mounted on glass slides, dewaxed in xylene, and treated with 3\% hydrogen peroxide in methanol for $30 \mathrm{~min}$. After hydration, endogenous biotin was blocked using an avidin/biotin blocking kit (Vector Laboratories). Both CD antibodies (1:200) were used according to the instructions of the suppliers. A biotinylated rabbit anti-mouse serum (1:200) was employed as the second antibody, followed by addition of avidin-biotinylated peroxidase complex (1:100). Peroxidase activity was developed using 3,3'-diaminobenzidine tetrahydrochloride with or without nickel enhancement.

\section{Results}

In situ hybridization for AE2 mRNA on liver showed that the AE2 transcript is expressed at relatively high levels in

Fig. 1A-C Localization of AE2 mRNA by in situ hybridization in human liver. A AE2/10 antisense riboprobe. B Similar field (sequential section) to $\mathbf{A}$ with corresponding AE2/10 sense riboprobe. $\mathbf{C}$ Different field with AE2/10 antisense riboprobe that shows the apparently decreasing gradient of hybridization signals in hepatocytes from zone 1 to zone 3 . White arrows indicate hybridization stain in bile ducts, and black arrows indicate stain in hepatocytes (or corresponding absence of stain in $\mathbf{B}$; micrograph in $\mathbf{B}$ was taken with low light intensity to visualize histological detail). $\times 460(\mathbf{A}, \mathbf{B}), \times 115$ (C). Bars $30 \mu \mathrm{m}(\mathbf{A}, \mathbf{B}), 120 \mu \mathrm{m}(\mathbf{C})$ 

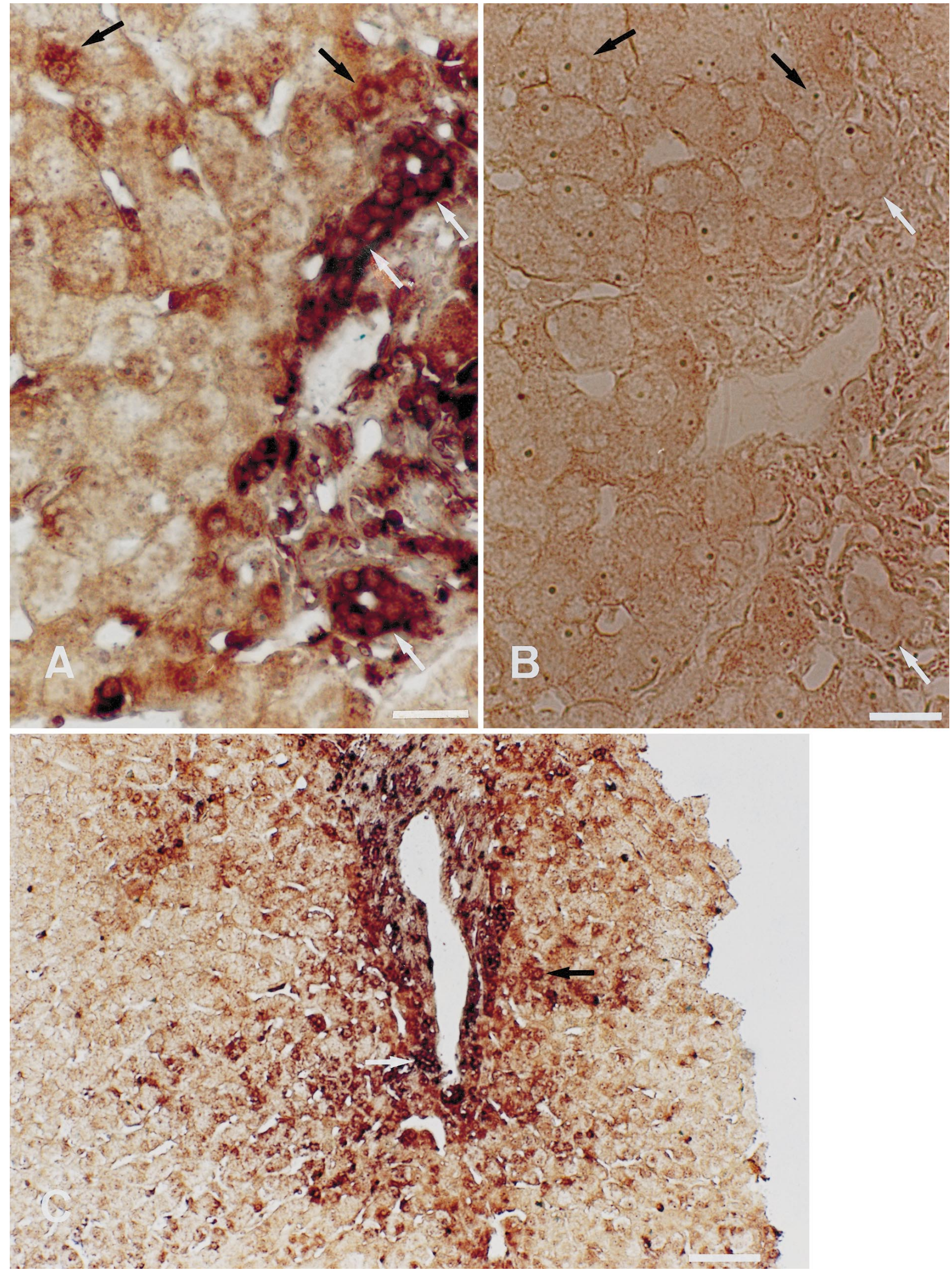


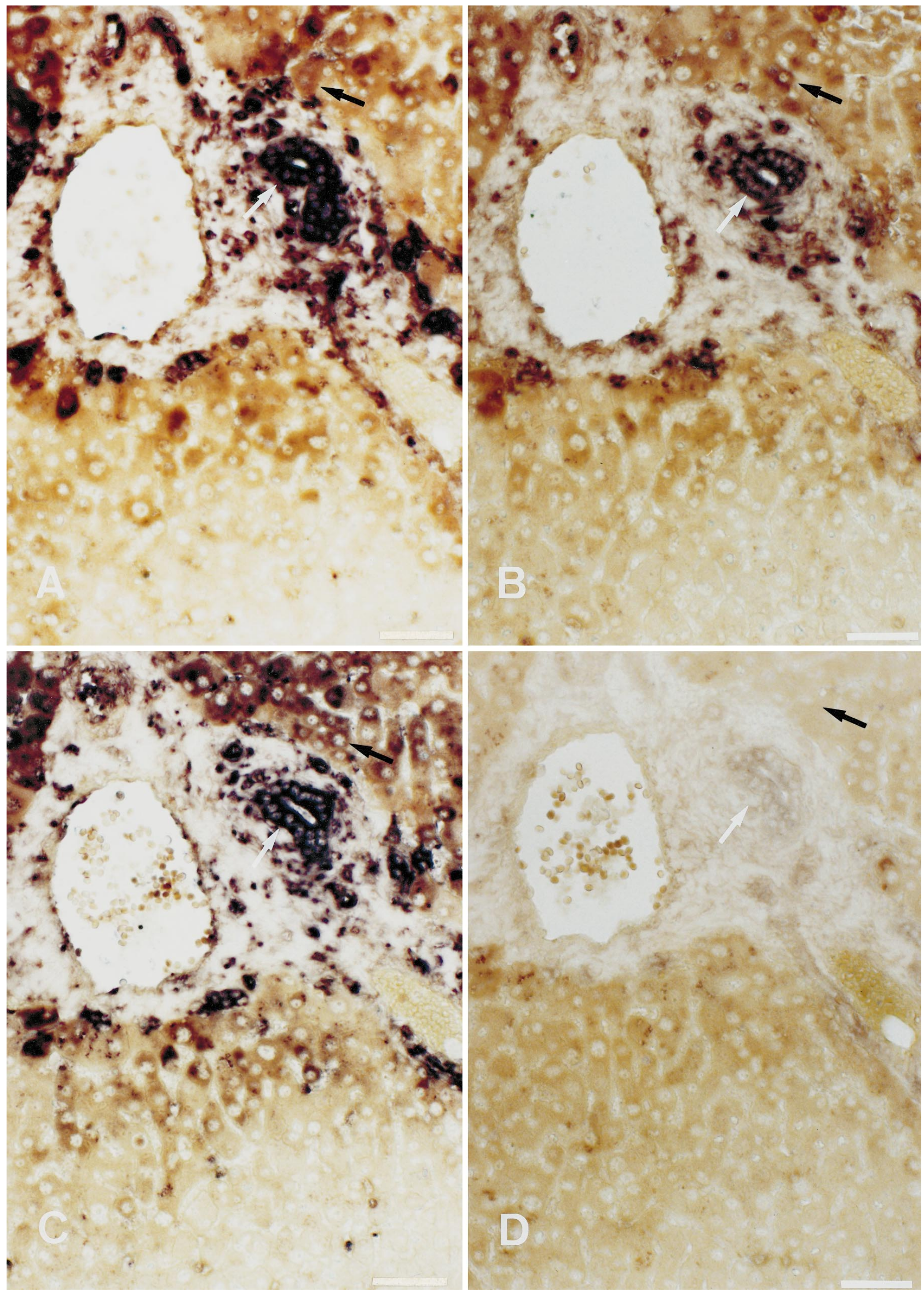


bile-duct epithelial cells. The AE2/10 antisense riboprobe (i.e., the riboprobe corresponding to the downstream third of the AE2 mRNA sequence) was obtained and tested first. It showed strong hybridization signals localized mainly to the cytoplasm of terminal and interlobular bile-duct epithelial cells, whereas weaker signals were also observed in the lining epithelial cells of larger intrahepatic ducts (Fig. 1). Control experiments on sequential sections using the AE2/10 sense riboprobe showed no label in any of the cells positively stained with the antisense riboprobe (Fig. 1). The specificity of hybridization signals obtained with the AE2/10 antisense riboprobe was further confirmed when two additional overlapping antisense riboprobes, AE2/11 and AE2/12, were tested on sequential sections, together with the AE2/10 antisense riboprobe, and also gave positive results (Fig. 2). However, as observed in Fig. 2, hybridization signals with the AE2/11 antisense riboprobe were weaker than those with the other two. Furthermore, signals with the AE2/12 antisense riboprobe were slightly less defined and tended to yield a higher background, which could be eliminated with more-stringent washings. No signals were observed in control experiments with either AE2/11 or AE2/12 sense riboprobes (data not shown). Control sections with RNase before hybridization as well as with omission of the probe also gave negative results (data not shown).

Some hepatocytes, mainly periportal ones in zone 1 (see Figs. 1, 2), showed AE2 mRNA signals in their cytoplasm. As for the bile-duct epithelial cells, these signals occurred with the three antisense riboprobes, the AE2/ 10 giving the best-defined results in the conditions tested. However, the overall intensity was generally weaker in hepatocytes than in bile-duct epithelial cells (Fig. 1A). In addition to these parenchymal cells, occasional staining was observed in endothelial cells of some vessels. Intense AE2 hybridization signals were found in a few scattered lymphomononuclear cells located both in the sinusoidal lumina as well as in portal infiltrates (Fig. 3A,C). Immunocytochemistry on reverse-phase sections of liver showed the presence of CD45R+ (UCHL1+) T lymphocytes (Fig. 3B,D), while similar experiments could not detect CD20+ (L26+) B cells within the liver (data not shown). This suggests that the few lymphomononuclear cells displaying hybridization signals might correspond to a subpopulation of $\mathrm{T}$ cells.

\section{Discussion}

The present study describes the in situ localization of the messenger RNA for AE2 in bile-duct epithelial cells and

4 Fig. 2A-D In situ hybridization in human liver using three overlapping antisense probes on sequential sections. A AE2/12 antisense riboprobe. B AE2/11 antisense riboprobe. C AE2/10 antisense riboprobe. D AE2/10 sense riboprobe. White arrows indicate hybridization stain in bile ducts, and black arrows indicate stain in hepatocytes (or corresponding absence of stain in $\mathbf{D}$; micrograph in $\mathbf{D}$ was taken with low light intensity to visualize histological detail). $\times 230$. Bars $60 \mu \mathrm{m}$ hepatocytes in the human liver. We have found that the AE2 message is expressed in bile-duct epithelial cells at relatively high levels, whereas a weaker AE2 mRNA signal is detected in the cytoplasm of some hepatocytes, mostly in zone 1 (periportal hepatocytes). These results are in line with our previous immunohistochemical results showing that the expression of the AE2 protein in the liver occurs at both the canaliculi and the luminal membranes of terminal and interlobular bile ducts (MartínezAnsó et al. 1994). These data on the localization of the AE2 gene expression in the liver are consistent with a possible role of AE2 protein in the generation of canalicular and ductular bile through bicarbonate secretion. It is currently assumed, especially in bile ducts, that an important proportion of the bile salt-independent bile flow is accounted for by the secretion of bicarbonate, this secretion representing the main determinant of the ductular component of bile flow.

It is known that the liver parenchyma is functionally heterogeneous, and a zonation of gene expression in the liver occurs (reviewed in Jungermann 1995). It is thus tempting to speculate about the potential significance of the apparent zonation of AE2 gene expression in periportal hepatocytes. Such predominance of AE2 gene expression in zone 1 might indicate more active participation of hepatocytes in this area in the secretion of bicarbonate to bile as compared to hepatocytes of the centrolobular region. It is interesting to note that our present data on zonation of AE2 mRNA expression agree well with previous immunohistochemical findings using the immunoperoxidase technique on fixed liver, in which canalicular AE2 immunostaining was located mainly in periportal hepatocytes (Martínez-Ansó et al. 1994). Certainly, more widespread detection of canalicular AE2 immunoreactivity was observed in the same study, when indirect immunofluorescence on fresh tissue (a procedure in which immunoreactivity is presumably better preserved) was carried out (Martínez-Ansó et al. 1994). These data taken together suggest that the AE2 gene is expressed in most hepatocytes, with an increasing expression rate from zone 3 to zone 1 (i.e., towards the vicinity of the bile ducts). Should the expression of the AE2 message occur in most hepatocytes, it might occur at levels below the threshold for its detection by in situ hybridization, especially in zone-2 and zone-3 hepatocytes. In fact, studies with Northern blot analysis of AE2 mRNA in mammalian livers are consistent in showing very low levels of expression in this organ (Alper et al. 1988). Furthermore, use of the reverse transcription-polymerase chain reaction was required in another study to measure the expression of the AE2 message in human liver biopsies (Prieto et al. 1993). Our present in situ hybridization data confirm that only a small subpopulation of cells within the liver have detectable AE2 mRNA and explain why total RNA preparations from liver homogenates show such apparently low levels of AE2 mRNA. Although hybridization signals are rather strong in bile-duct epithelial cells, these cells only represent 3-5\% of the total cell number in a healthy human liver, whereas hepatocytes account 

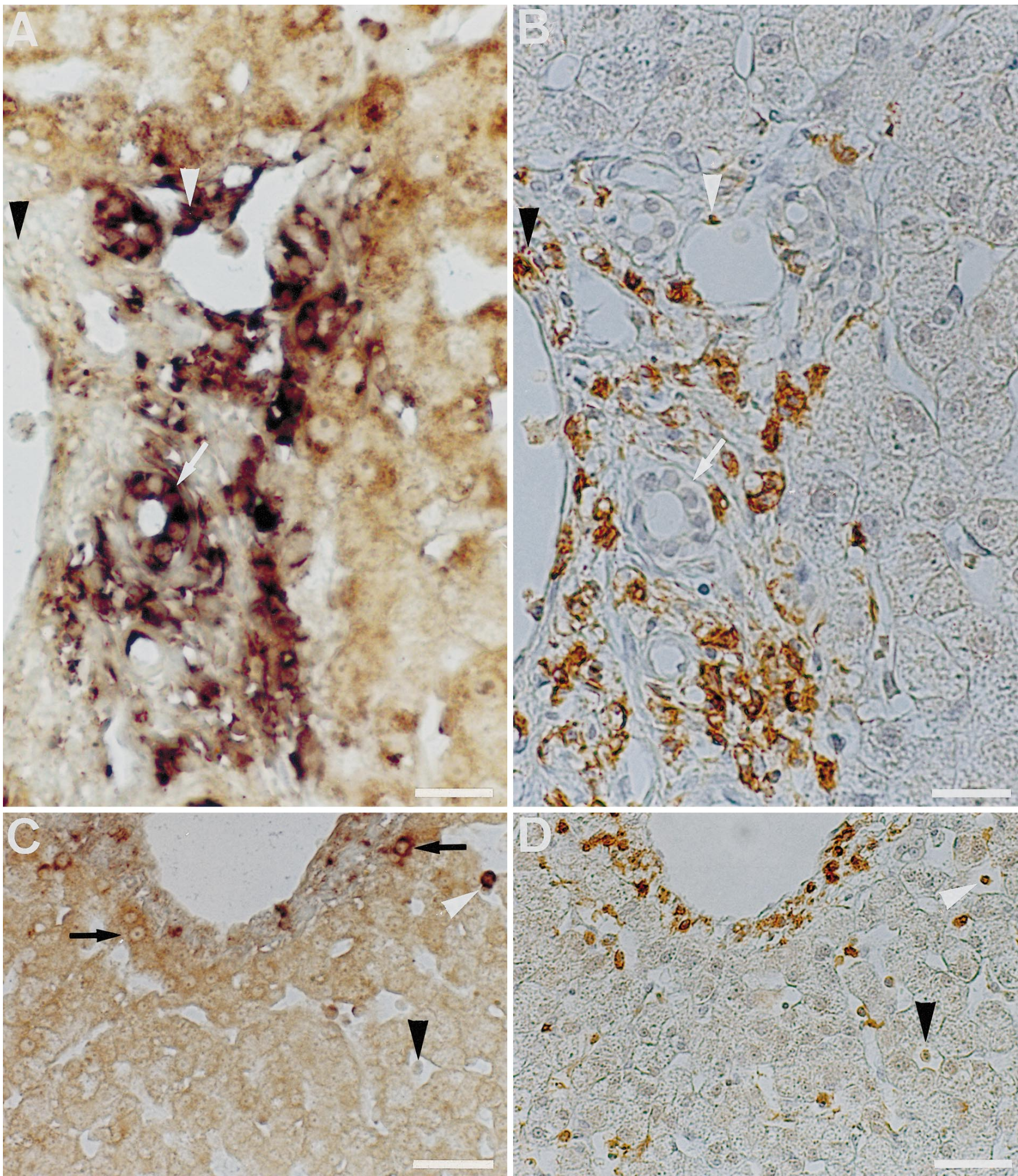

Fig. 3A-D AE2 mRNA detection and CD45R labeling in liver lymphomononuclear cells. A, C In situ hybridization with AE2/10 antisense riboprobe. B, D Immunostaining using anti-CD45R (UCHL1) monoclonal antibody on reverse-phase sections corresponding to fields in $\mathbf{A}$ and $\mathbf{C}$, respectively. Note that some lymphomononuclear cells with peroxidase stain in $\mathbf{B}$ and $\mathbf{D}$ also show hy-

bridization signals in $\mathbf{A}$ and $\mathbf{C}$, respectively. White arrowheads indicate lymphomononuclear cells that are seemingly AE2+ and CD45R+; black arrowheads indicate apparent $\mathrm{T}$ cells that are $\mathrm{AE} 2-/ \mathrm{CD} 45 \mathrm{R}+$; white arrows indicate bile ducts; and black arrows indicate hepatocytes with hybridization signals. $\times 460$ (A, B), ×230 (C, D). Bars $30 \mu \mathrm{m}(\mathbf{A}, \mathbf{B}), 60 \mu \mathrm{m}(\mathbf{C}, \mathbf{D})$ 
for up to $80 \%$ of liver cell mass (Blovin et al. 1977; Alpini et al. 1994). Among other cells that comprise the remaining liver-cell population, a few vessel cells as well as scattered pit cells (i.e., resident large granular lymphocytes) show detectable hybridization signals. Signals in lymphomononuclear cells are sometimes strong, and the hybridization pattern obtained with riboprobes is identical to the pattern observed in bile-duct epithelial cells and hepatocytes. All three overlapping antisense riboprobes gave positive results, the AE2/10 antisense riboprobe showing the best-defined signals with rather low background. However, no AE2 immunostaining was observed in liver lymphocytes with our AE2 monoclonal antibody (E. Martínez-Ansó, J.F. Medina, and J. Prieto, unpublished observations). The reason for this apparent paradox is unknown, but it is possible that the antibody, which was produced against a synthetic peptide (cf. Martínez-Ansó et al. 1994), could not recognize the corresponding AE2 epitope, because it was less accessible in lymphomononuclear cells than in polarized liver parenchymal cells (hepatocytes and bile-duct epithelial cells). Moreover, other (monoclonal and polyclonal) antibodies against different AE2 epitopes (i.e., different AE2 peptides) also failed to stain human, rat, and rabbit liver lymphocytes, while they could recognize liver parenchymal cells (E. MartínezAnsó, J.F. Medina, and J. Prieto, unpublished observations). Additional evidence for the expression of the AE2 transcript in lymphocytes can be found in our previous report that peripheral blood mononuclear cells appear to express AE2 mRNA, as detected by the reverse transcription-polymerase chain reaction on total RNA isolated from these cells (Prieto et al. 1993).

Regarding the type of lymphomononuclear cells within the liver that display hybridization signals with the antisense AE2 riboprobes, they appear to correspond to a subpopulation of liver $\mathrm{T}$ cells. This is suggested by the fact that immunocytochemistry on reverse-phase sections of liver with CD markers showed that most of lymphomononuclear cells present in the liver are CD45R+ and CD20- T cells, which is in agreement with previous reports (Volpes et al. 1991, and references therein).

Finally, it should be noted that the liver specimens used in this study were apparently normal in a functional context, but most were taken from patients who had undergone operations because of metastases or cysts. Thus, we can only assume that our results correspond to the normal situation.

Acknowledgements The authors wish to express their gratitude to Dr. E. Martínez-Ansó for his valuable help with color illustrations. We are also grateful to the staff of the Department of Pathology (University Clinic of Navarra) for their assistance with liver preparations.

\section{References}

Alper SL (1994) The band 3-related AE anion exchanger gene family. Cell Physiol Biochem 4:265-281
Alper SL, Kopito RR, Libresco SM, Lodish HF (1988) Cloning and characterization of a murine band 3-related cDNA from kidney and from a lymphoid cell line. J Biol Chem 263:1709217099

Alpini G, Phillips JO, LaRusso NF (1994) The biology of biliary epithelia. In: Arias IM, Boyer JL, Fausto N, Jakoby WB, Schachter DA, Shafritz D (eds) The liver: biology and pathobiology, 3rd edn. Raven Press, New York, pp 623-653

Blovin A, Bolender RP, Weibel E (1977) Distribution of organelles and membranes between hepatocytes and nonhepatocytes in the rat liver parenchyma. J Cell Biol 72:441-455

Brosius FC III, Nguyen K, Stuart-Tilley AK, Haller C, Briggs JP, Alper SL (1995) Regional and segmental localization of AE2 anion exchanger mRNA and protein in rat kidney. Am J Physiol 269:F461-F468

Chomczynski P, Sacchi N (1987) Single-step of RNA isolation by acid guanidinium thiocyanate-phenol-chloroform extraction. Anal Biochem 162:156-159

Chow A, Dobbins JW, Aronson PS, Igarashi P (1992) cDNA cloning and localization of a band 3-related protein from ileum. Am J Physiol 263:G345-G352

Demuth DR, Showe LC, Ballantine M, Palumbo A, Fraser PJ, Cioe L, Rovera G, Curtis PJ (1986) Cloning and structural characterization of a human non-erythroid band 3-like protein. EMBO J 5:1205-1214

Fairbanks G, Steck TL, Wallach DFH (1971) Electrophoretic analysis of the major polypeptides of the human erythrocyte membrane. Biochemistry 10:2606-2616

Gehrig H, Müller W, Appelhans H (1992) Complete nucleotide sequence of band 3 related anion transport protein AE2 from human kidney. Biochim Biophys Acta 1130:326-328

Gibson SJ, Polak JM (1990) Principles and applications of complementary RNA probes. In: Polak JM, McGee JO (eds) In situ hybridization: principles and practice. University Press, Oxford, pp 81-94

Hsu SM, Raine L, Fanger H (1981) Use of avidin-biotin-peroxidase complex $(\mathrm{ABC})$ in immunoperoxidase techniques: a comparison between $\mathrm{ABC}$ and unlabeled antibody (PAP) procedures. J Histochem Cytochem 29:577-580

Jennings ML (1992) Anion transport proteins. In: Seldin DW, Giebischs G (eds) The kidney physiology and pathophysiology. Raven Press, New York, pp 503-535

Jons T, Warrings B, Jons A, Drenckhahn D (1994) Basolateral localization of anion exchanger 2 (AE2) and actin in acid-secreting (parietal) cells of the human stomach. Histochemistry 102:255263

Jungermann K (1995) Zonation of metabolism and gene expression in liver. Histochemistry 103:81-91

Kopito RR (1990) Molecular biology of the anion exchanger gene family. Int Rev Cytol 123:177-199

Kopito RR, Lee BS, Simmons DM, Lindsey AE, Morgans CW, Schneider K (1989) Regulation of intracellular $\mathrm{pH}$ by a neuronal homolog of the erythrocyte anion exchanger. Cell 59:927-937

Kudrycki KE, Newman PR, Shull GE (1990) cDNA cloning and tissue distribution of mRNAs for two proteins that are related to the band $3 \mathrm{Cl}^{-} / \mathrm{HCO}_{3}^{-}$exchanger. J Biol Chem 265:462-471

Lindsey AE, Schneider K, Simmons DM, Baron R, Lee BS, Kopito RR (1990) Functional expression and subcellular localization of an anion exchanger cloned from choroid plexus. Proc Natl Acad Sci USA 87:5278-5282

Linn SC, Kudrycki KE, Shull GE (1992) The predicted translation product of a cardiac AE3 mRNA contains an $\mathrm{N}$ terminus distinct from that of the brain $\mathrm{AE} 3 \mathrm{Cl}^{-} / \mathrm{HCO}_{3}{ }^{-}$exchanger. $\mathrm{J}$ Biol Chem 267:7927-7935

Linn SC, Askew G, Menon AG, Shull GE (1995) Conservation of an AE3 $\mathrm{Cl}^{-} / \mathrm{HCO}_{3}{ }^{-}$exchanger cardiac-specific exon and promoter region and AE3 mRNA expression patterns in murine and human hearts. Circ Res 76:584-591

Lukakovic MF, Feinstein MB, Sha'afi RI, Perrie S (1981) Purification of stabilized band 3 protein of the human erythrocyte membrane and its reconstitution into liposomes. Biochemistry 20:3145-3151 
Lux SE, John KM, Kopito RR, Lodish HF (1989) Cloning and characterization of band 3, the human erythrocyte anion-exchange protein (AE1). Proc Natl Acad Sci USA 86:9089-9093

Martínez-Ansó E, Castillo JE, Díez J, Medina JF, Prieto J (1994) Immunohistochemical detection of chloride/bicarbonate anion exchangers in human liver. Hepatology 19:1400-1406

Mason MJ, Smith ID, Garcia-Soto JJ, Grinstein S (1989) Internal pH-sensitive site couples $\mathrm{Cl}^{-}-\mathrm{HCO}_{3}{ }^{-}$exchange to $\mathrm{Na}^{+}-\mathrm{H}^{+}$antiport in lymphocytes. Am J Physiol 256:C428-C433

Medina JF, Acín A, Prieto J (1997) Molecular cloning and characterization of the human AE2 anion exchanger (SLC4A2) gene. Genomics 39:74-85

Negrini C, Rivolta MN, Kalinec F, Kachar B (1995) Cloning of an organ of Corti anion exchanger 2 isoform with a truncated C-terminal domain. Biochim Biophys Acta 1236:207-211

Parkkila S, Rajaniemi H, Kellokumpu S (1993) Polarized expression of a band 3-related protein in mammalian sperm cells. Biol Re$\operatorname{prod} 49: 326-331$
Prieto J, Qian C, García N, Díez J, Medina JF (1993) Abnormal expression of anion exchanger genes in primary biliary cirrhosis. Gastroenterology 105:572-578

Tanner MJA, Martin PG, High S (1988) The complete amino acid sequence of the human erythrocyte membrane anion-transport protein deduced from the cDNA sequence. Biochem $\mathbf{J}$ 256:703-712

Vázquez JJ, Vázquez M, Idoate MA, Montuenga L, Martínez-Ansó E, Castillo JE, García N, Medina JF, Prieto J (1995) Anion exchanger immunoreactivity in human salivary glands in health and Sjögren's syndrome. Am J Pathol 146:1422-1432

Volpes R, Oord JJ van den, Desmet VJ (1991) Memory T cells represent the predominant lymphocyte subset in acute and chronic liver inflammation. Hepatology 13:826-829

Yannoukakos D, Stuart-Tilley A, Fernandez HA, Fey P, Duyk G, Alper SL (1994) Molecular cloning, expression and chromosomal localization of two isoforms of the AE3 anion exchanger from human heart. Circ Res 75:603-614 